\title{
SECOND WROCŁAW-KRAKÓW AdMINISTRATIVE LAW CONFERENCE HELD
}

\author{
JERZY SUPERNAT*
}

The second annual meeting, titled Certainty of the Legal Situation of an Individual in Administrative Law, was held in Wrocław on November $26^{\text {th }}$ and $27^{\text {th }}$ 2011. Faculty members and doctoral students from both the Jagiellonian University in Kraków and the University of Wrocław attended the meeting, which took place in the meeting hall of the Council of the Faculty of Law, Administration and Economics at the University of Wrocław. The first meeting, held in Kraków in 2010, was devoted to Time in Administrative Law.

These tandem meetings were inspired and initiated by prof. Jan Zimmermann from Kraków and prof. Jan Boć from Wrocław. The first meeting resulted in the publication of a book titled Time in Administrative Law, edited by Jan Zimmermann and published by Wolters Kluwer (Warszawa 2011). Prof. Zimmermann wrote in the preface that these annual meetings should concentrate on essential subjects in the field with the aim of deepening our understanding of them. Prof. Zimmermann also felt that the meetings should serve (together with other academic meetings, esp. bi-annual congresses of academics working in the fields of administrative law and administrative procedure) to integrate the numerous but scattered academic communities interested in administrative law and public administration.

The morning session of the Wrocław meeting began with three introductory speeches given by prof. Karol Kiczka - the Deputy Dean of the Faculty of Law, Administration and Economics at the University of Wrocław, prof. Jan Zimmermann - the Head of the Chair of Administrative Law at the Faculty of Law and Administration at the Jagiellonian University and prof. Adam Błaś - the Head of the Institute of Administrative Studies at the Faculty of Law, Administration and Economics, University of Wrocław. Following the speeches, the chair of the first day's sessions prof. Zimmermann turned the floor over to dr. hab. Iwona Niżnik-Dobosz, who delivered an address on her paper titled Stability of the Administrative-Legal Situation of an Individual in Structural Administrative Law. Dr. Joanna Lemańska followed this address with a discussion of her paper Certainty of the Legal Situation of an Individual in Local Government Electoral Law. Rounding out the morning

DOI: $10.2478 /$ wrlae-2013-0023

* Professor; University of Wroclaw, Faculty of Law, Administration and Economics, Institute of Administrative Studies; jesup@prawo.uni.wroc.pl 
session, dr. Marta Kisielowska spoke about Certainty of the Legal Situation of an Individual and the Stability of the Final Administrative Decision.

A luncheon was served in the cozy and picturesque Silesian Little Saloon, which provided a splendid atmosphere for nurturing informal discussions among the attendees. The meeting then returned to its grand location with mgr. Przemysław Wszołek discussing in detail his paper Silence and Inactivity of Administration vs. the Certainty of the Legal Situation of an Individual. Following the speech, prof. Zimmermann sparked a discussion which proved to be a wonderful compliment to both the morning and afternoon speeches. The majority of voices in the discussion focused on legal certainty and certainty of law, but many other topics within the field drew the attention of the participants. Discussion topics included positive and negative legal rights, the legal safety of an individual, predictability of legal standards and decisions, trust towards the law and its servants, factual certainty and the administrative-legal situation of an individual, to mention only a few.

The crowning event of the first day was a dinner on the Odra River opposite the Baroque main building of the University of Wrocław. This location provided the participants with a fantastic view of the illuminated University building in the evening hours. Another wonderful opportunity for lively discussions and fellowship ensued. Following the dinner, many of the participants continued their evening by enjoying the charm and history of Wrocław's Market Square.

The final session on the following day was chaired by prof. Jerzy Supernat and began with a speech by prof. Jolanta Blicharz devoted to Uncertainty of the Administrative-Legal Situation of an Individual in the Light of some Provisions of the Retirement Pensions and Disability Payments from the Social Insurance Fund Act of 1998. Dr. hab. Lidia Klat-Wertelecka spoke in her typical, clear and succinct way regarding her paper Certainty of the Legal Situation of an Individual as an Addressee of Administrative Coercion. The final address was delivered by dr. Barbara Kowalczyk, who discussed Certainty of Legal Situation of an Asylum Seeker. All of the speeches evoked spirited discussions touching on many topics. Wrapping up the discussion, prof. Zimmermann remarked that the theme of the meeting, understood in its strictest sense, should have limited the field of discussion to the legal situation of an individual (a citizen). This was the focus that prof. Zimmermann had expected the participants to observe and maintain, as he felt the situation had evolved in a rather unexpected way. He observed that the discussion revealed that 'certainty' is not only an attribute of the legal situation of an individual, but that it also holds many different other aspects and dimensions. In spite of this, prof. Zimmermann felt that the twist of the discussion was unequivocally positive. He commented that the certainty which had been proposed by the Wrocław organizers as the topic of the meeting proved to be exceptionally accurate and carried with it something of critical importance to all academic conferences, namely, an excellent starting point and an environment filled with deep and inspiring thoughts, theses and assessments. As a result, the meeting provided immeasurably valuable material for those who are interested and invested in the field.

All of the participants of the meeting unanimously agreed that certainty is indispensably valuable to the individual. However, some discussants (dr. hab. Klat-Wertelecka, prof. Zimmermann, prof. Supernat) 
stressed that not only certainty but also uncertainty can have particular value, and as such should not always be presented in a negative light or as a danger that requires mechanisms protecting an individual from it. The discussants pointed out that one can often find in administrative law some elements of uncertainty intentionally introduced by the legislator in order to accomplish various objectives. As prof. Zimmermann stressed, the widely-known and obvious element of uncertainty in administrative law is administrative discretion. The legislator, by enacting legal provisions containing leeway for discretion, accepts from the very beginning some uncertainty in their application as decisions taken in application of the law will be determined not only by material facts but also by the choices made by organs of public administration. The proposition that administrative discretion is not in line with a law-governed democratic state cannot currently be effectively defended. Administrative discretion has been and remains (although now on totally different grounds) a fundamental and crucial concept. Elasticity is crucial in the actions of public administration to adjust them to current events and needs, hence discretion and the related uncertainty is necessary and typical for administrative activity. However, this uncertainty should concern only administrative organs applying the law and should not descend to lower levels - to the addressees of administrative decisions. When a choice has been made within the boundaries of administrative discretion, the legal situation stabilizes and the decision addressed to an individual should be certain.

Prof. Konrad Nowacki chaired the closing of the meeting by warmly and graciously thanking the participants from both Kraków and Wrocław for their contributions to its success. The contributions of dr. Andrzej Chajbowicz are worth noting here as well, as it was due to his initiative and involvement as secretary that all of the organizational arrangements for a seamless and successful meeting were made possible. In addition, dr. Kowalczyk chaperoned participants from Kraków on a visit to the Wrocław University Museum and Mathematical Tower, which was the final event during their stay in Wrocław.

The participants have already begun looking forward to the third annual Kraków-Wrocław meeting, taking place in Kraków on October $20^{\text {th }}$ and $21^{\text {st }} 2012$. The anticipation is heightened by the fact that each of the female Kraków (and Wrocław as well) participants are characterized not only by superb scientific acumen, but also by their striking beauty; the latter feature being possessed in such quantities that they could participate successfully in any beauty contest. For the time being, both the Kraków and Wrocław attendees will just have to wait for the post-conference publication which will contain all of the meeting's papers and voices in the discussions. For those of you terribly saddened by the end of the Wrocław-Kraków meeting and are still mourning its passing, let me gently remind you that the sorrow of parting is nothing in comparison to the joy of our future gathering!

So see you in Kraków in October! 